\title{
ARBUSCULAR MYCORRHIZAL FUNGI STATUS OF SOME CROPS IN THE CROSS RIVER BASIN OF NIGERIA
}

INIOBONG E. OKON AND M. G. SOLOMON

(Received 7, August 2013; Revision Accepted 29, November 2013)

\begin{abstract}
The incidence of arbuscular mycorrhizal fungi (AMF) colonization and rhizospheric spore prevalence of ten crops was studied in relation to their foliar concentration of nitrogen, phosphorus and potassium in the Calabar area of the Cross River Basin of Nigeria in order to determine their mycorrhizal status. All crops studied had an incidence of mycorrhizal colonization including Talinum triangulare a member of Portulacaceae family. The highest percentage AMF colonization of $97.60 \%$ and rhizospheric spore density of 112 spores $/ 5 \mathrm{~g}$ soil were found in Arachis hypogea while Talinum triangulare and Telfairia occidentalis had the lowest percentage AMF colonization of $30.90 \%$ and rhizospheric spore density of 10 spores $/ 5 \mathrm{~g}$ soil respectively. There was no correlation between the percentage AMF colonization and the rhizospheric spore density of the crops sampled. Foliar phosphorus concentration was highest in $A$. hypogea, $(1.20 \%)$, for potassium it was in Colocasia esculenta $(9.3 \%)$ while $T$. occidentalis had the highest foliar nitrogen concentration $(4.9 \%)$. There was no significant relationship between foliar nutrient concentration and AM fungi colonization or rhizospheric spore density.
\end{abstract}

KEYWORDS: AMF, Colonization, Spore density, Foliar nutrients, Cross River Basin of Nigeria.

\section{INTRODUCTION}

Arbuscular mycorrhizal fungi (AMF) are found in most agricultural soils (Ryan and Angus, 2003). They are broad-host ranged and colonize the roots of most crops and weeds. About $90 \%$ of terrestrial plants species have been found to be colonized by mycorrhizal fungi (Gadkar et al., 2001). This high percentage notwithstanding, non-mycorrhizal plants have been found in some species belonging to Araceae, Caryophyllaceae, Compositae, Cruciferae, Gramineae, Onagraceae, Polygonaceae, and Portulacaceae families (Berch et al., 1998). Being obligate symbionts, AMF depend solely on the host plants for their carbon needs (Fitter and Merryweather, 1992). The host plant benefits immensely from arbuscular mycorrhizal association in the areas of nutrient and water uptake (Okon et al., 1996; Fagbola et al., 1998). Arbuscular mycorrhizal fungi are very important in increasing the ability of the host plant to absorb immobile or fixed ions such as phosphorus, zinc and copper in acidic or alkaline soils as well as in the absorption of water and nitrogen (Sharif and Moawad, 2006). Besides, arbuscular mycorrhizae have been implicated with the production of acid and alkaline phosphatase for hydrolysis of organic phosphates thereby making them available to the plant roots (Tarafdar and Marschner, 1994). This enhanced nutrient and water uptake results in improved nutrition, increased plant growth and crop yield. Nowadays much emphasis is laid on sustainable agriculture. Arbuscular mycorrhizal fungi association with crops is considered to be of great significance in sustainable agriculture (Gianinazzi and Scheuepp, 1994; Sunilkumar et al., 2012).

Abelmoschus esculentus, Arachis hypogea, Capsicum annum, Colocasia esculenta, Ipomea batatas, Manihot esculenta, Talinum triangulare, Telfairia occidentalis, Vigna unguiculata and Zea mays are all agricultural crops commonly grown in Calabar in the Cross River basin of Nigeria. Although the basin has produced much of these crops to the satisfaction of its human inhabitants for a long time, there has never been any investigation on their mycorrhizal status.

The objective of this work was therefore to investigate the mycorrhizal status of these crops in relation to their foliar nutrient (nitrogen, phosphorus and potassium) concentration and available arbuscular mycorrhizal fungi spores in their respective rhizosphere with a view to using mycorrhizal inoculation to increase their production.

\section{MATERIALS and METHODS Experimental site}

Samples of roots and rhizosphere soil were collected within Calabar in the Cross River Basin area located between latitude $4.96^{\circ} \mathrm{N}$ and longitude $8.31^{\circ} \mathrm{E}$ at an elevation of $700 \mathrm{~km}$ above the sea level (Tageo.com 2013). Physicochemical analysis of the soil revealed that

Iniobong E. Okon, Department of Botany, University of Calabar, P.M.B. 1115, Calabar, Nigeria.

M. G. Solomon, Department of Soil Science, University of Calabar, P.M.B. 1115, Calabar, Nigeria. 
it is characteristically sandy loam consisting of $75.6 \%$ sand, $7.7 \%$ silt and $16.7 \%$ clay. The chemical composition of the soil was $0.10 \%$ total $\mathrm{N}$; $35.5 \mathrm{ppm} \mathrm{P}$; $0.30 \mathrm{cmol} \mathrm{kg}^{-1} \mathrm{~K} ; 1.18 \%$ organic carbon and $2.04 \%$ organic matter.

\section{Sampling procedure and species selection}

Ten most commonly grown crops of the Cross River Basin were selected for this study. These were Arachis hypogea, Vigna unguiculata, Zea mays, Capsicum annum, Colocasia esculenta, Ipomea batatas, Manihot esculenta, Abelmoschus esculentus, Talinum triangulare, Telfairia occidentalis. This list comprised of two legume, one cereal, one spice, three tuber and three vegetable crops respectively. These crops which were all between $4-5$ months old on the farms were carefully uprooted with the surrounding rhizospheric soil, transferred immediately into labeled polyethylene bags and taken to the laboratory. Sampling was carried out in four randomly selected locations within the experimental site.

\section{Estimation of arbuscular mycorrhizal fungi (AMF) colonization of plant roots}

Representative samples of fine terminal feeder roots were collected from each species harvested. These were washed clear of soil particles in running tap water and fixed in $50 \%$ ethanol. Clearing and staining of roots was done following the modified procedure of Koske and Gemma (1989). Percentage AMF colonization was assessed using the gridline intersect method of Giovanetti and Mosse (1980). Stained roots were scanned under a dissecting microscope along vertical and horizontal gridlines at a magnification of $\times 45$. Presence of colonization was recorded at each point where a stained root with hyphae, vesicles or arbuscules intersected a line. Percentage root colonization was calculated as:

$$
\frac{\text { No. of root/gridline intersects with colonization }}{\text { Total no. of root/gridline intersects counted }} \times \frac{100}{1}
$$

\section{Recovery and enumeration of AMF spores from the rhizosphere}

Rhizospheric soil of each crop was air dried and homogenized. AMF spores associated with each crop were then extracted from their respective rhizosphere using the wet sieving technique of Daniels and Skipper (1982). The soil fractions of between less than $106 \mu \mathrm{m}$ and $53 \mu \mathrm{m}$ were collected from $100 \mathrm{~g}$ of air dried soil and the spores were then further concentrated by $70 \%$ sucrose solution centrifugation at $3000 \mathrm{rpm}$ for 4 minutes. The number of spores per $100 \mathrm{~g}$ of soil was determined by counting under a dissecting microscope at $\times 45$ magnification. This value was then presented per $5 \mathrm{~g}$ of soil through simple proportion calculation.

\section{Plant foliar nutrient analyses}

Leaves from the crops sampled were oven dried, ground into powder and analyzed for total foliar nitrogen, phosphorus and potassium concentrations. Total foliar nitrogen was determined by Micro-Kjeldal digestion method while total foliar phosphorus was determined colorimetrically by Vanado-Molybdate method and total foliar potassium was determined by flame photometery all as described by Juo (1979).

\section{Statistical Analysis}

All data were analyzed by combined analysis of variance using the Windows version of Statistical Analysis System (SAS 1996). Mean values were compared using Duncan's Multiple Range Test (DMRT) at 0.05 level of probability when the F-ratio was significant.

\section{RESULTS}

Arbuscular mycorrhizal fungi spore prevalence and root colonization

Rhizospheric soil samples of the ten crops contained AMF spores. The lowest number of spore count, 10 spores $/ 5 \mathrm{~g}$ soil, was obtained from Telfairia occidentalis rhizosphere while the highest 112 spores $/ 5 \mathrm{~g}$ soil, was from Arachis hypogea rhizosphere. Rhizospheric soil spore densities were not significantly different in $C$. annum and $M$. esculenta or among $I$. batatas, $T$. triangulare, $C$. esculenta and Z. mays (Table 1).

The highest percentage AMF colonization of 97.6\%, was observed in Arachis hypogea while the least of $30.9 \%$, was observed in Talinum triangulare. There was however no significant difference between the percentage AMF colonization of roots in $C$. annum and $T$. occidentalis or among $V$. unguiculata, I. batatas, $M$. esculenta and $Z$. mays respectively (Table 1 ).

\section{Foliar nutrient concentration}

Arachis hypogea gave the highest foliar phosphorus concentration, the highest foliar nitrogen concentration was obtained from Telfairia occidentalis while Colocasia esculenta had the highest foliar potassium concentration followed by Capsicum annum and Ipomea batatas respectively. It is worthy of note that no detectable trace of potassium was found in the leaves of $A$. hypogea leaves. 
Table 1: AMF colonization and foliar NPK concentration (\%) of some crops in the Cross River Basin of Nigeria.

\begin{tabular}{|c|c|c|c|c|c|}
\hline Crop & Phosphorus & Nitrogen & Potassium & $\begin{array}{l}\% \text { AMF } \\
\text { Colonization }\end{array}$ & $\begin{array}{l}\text { Spore } \\
15 \mathrm{~g} \text { soil }\end{array}$ \\
\hline
\end{tabular}

\begin{tabular}{llllll} 
A. hypogea & $* 1.20 \mathrm{a}$ & $4.90 \mathrm{~b}$ & $0.00 \mathrm{i}$ & $97.60 \mathrm{a}$ & $112 \mathrm{a}$ \\
V. unguiculata & $0.21 \mathrm{~cd}$ & $4.06 \mathrm{~d}$ & $6.10 \mathrm{~d}$ & $40.70 \mathrm{~d}$ & $58 \mathrm{~b}$ \\
A. esculentus, & $0.38 \mathrm{~b}$ & $3.43 \mathrm{e}$ & $0.60 \mathrm{~h}$ & $32.00 \mathrm{e}$ & $41 \mathrm{~d}$ \\
C. annum & $0.25 \mathrm{c}$ & $5.25 \mathrm{ab}$ & $8.80 \mathrm{~b}$ & $64.00 \mathrm{c}$ & $48 \mathrm{c}$ \\
I. batatas, & $0.24 \mathrm{c}$ & $3.05 \mathrm{f}$ & $7.70 \mathrm{c}$ & $38.40 \mathrm{~d}$ & $24 \mathrm{e}$ \\
M. esculenta & $0.26 \mathrm{c}$ & $4.27 \mathrm{c}$ & $3.90 \mathrm{f}$ & $37.86 \mathrm{~d}$ & $49 \mathrm{c}$ \\
T. triangulare & $0.24 \mathrm{c}$ & $4.06 \mathrm{~d}$ & $3.10 \mathrm{~g}$ & $30.90 \mathrm{e}$ & $29 \mathrm{e}$ \\
T. occidentalis & $0.36 \mathrm{~b}$ & $5.36 \mathrm{a}$ & $5.10 \mathrm{de}$ & $62.00 \mathrm{c}$ & $10 \mathrm{f}$ \\
C. esculenta & $0.26 \mathrm{c}$ & $3.50 \mathrm{e}$ & $9.30 \mathrm{a}$ & $67.63 \mathrm{~b}$ & $32 \mathrm{e}$ \\
Z. mays. & $0.14 \mathrm{~d}$ & $0.34 \mathrm{~g}$ & $5.60 \mathrm{~d}$ & $40.00 \mathrm{~d}$ & $25 \mathrm{e}$ \\
\hline
\end{tabular}

*Values are means of four replicates. Means in the same column followed by different letters are significantly different at $p<0.05$ according to Duncan's multiple range test.

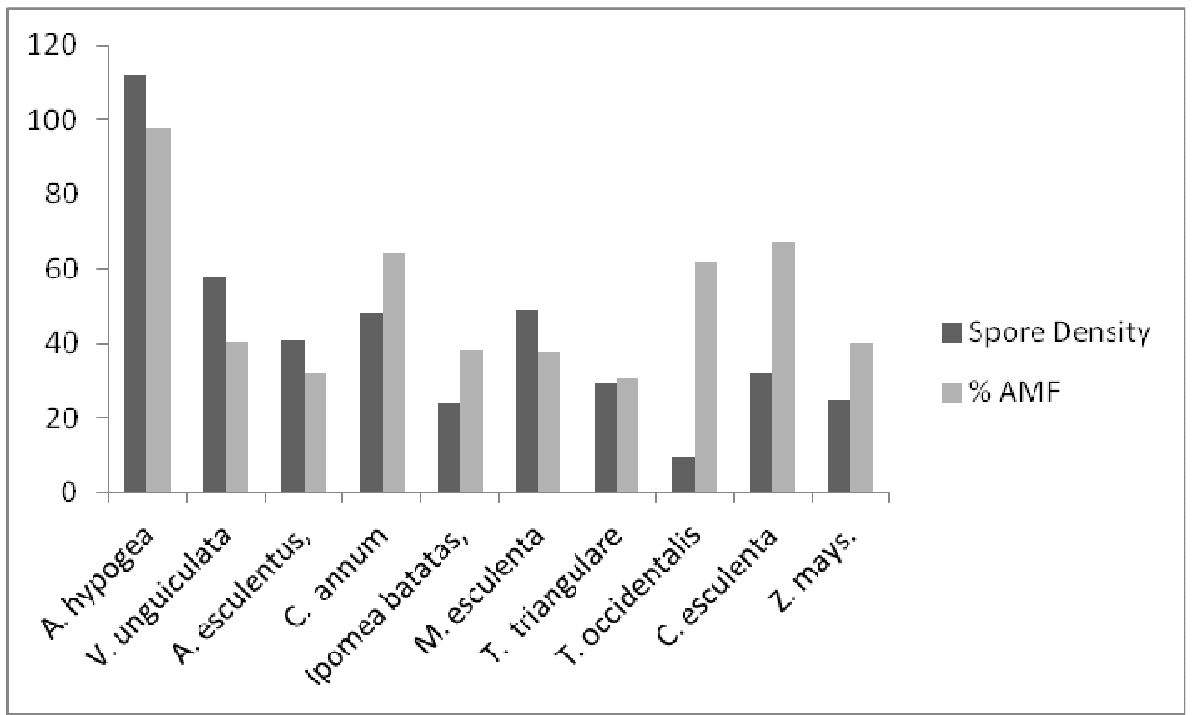

Fig. 1: \% AMF colonization and rhizospheric spore density

\section{DISCUSSION}

From our investigation, we have established that Arachis hypogea, Vigna unguiculata, Abelmoschus esculentus, Capsicum annum, Ipomea batatas, Manihot esculenta, Talinum triangulare, Telfairia occidentalis, Colocasia esculenta and Zea mays are all associated with arbuscular mycorrhizal fungi colonization (Table 1). This is a confirmation that most agricultural crops are colonized by mycorrhizal fungi. It is interesting to observe mycorrhizal colonization in Talinum triangulare roots which is a member of Portulacaceae family which is known to be among the unusual few families where only isolated species form mycorrhizae (Sieverding, 1991; Berch et al., 1998). The highest percentage colonization in Arachis hypogea may be connected with its rooting morphology as well as being a legume. Arachis hypogea has thick roots with few branches which according to Baylis (1975) have greater dependence on mycorrhizal association. Isobe and Tsuboki (1998), have found higher AMF colonization in leguminous than in graminaceous crops. Thus as a legume, $A$. hypogea probably favoured mycorrhizal colonization to assist the symbioses with Rhizobium (Bethlenfalvay and Newton, 1991).

Our findings also showed that all the rhizospheric soil samples contained spores. This confirms that arbuscular mycorrhizal fungi are found in all agricultural soils. However, apart from the case with Arachis hypogea where there was relationship between the high percentage of AMF colonization and spore prevalence, there was no such relationship in other crops. This is an indication that root colonization may not necessarily be a function of spore number in the soil but a reflection of the response of the host plant to the inoculum. It has been suggested that different plant species differ in their degree of AMF support (Bagyaraj and Manjunath, 1980) and also their dependency on arbuscular mycorrhizal fungi (Plenchette et al., 1993).

Foliar phosphorous concentration was correspondingly highest in $A$. hypogea. This could have possibly resulted from the increased amount extracted from the soil by the abundant AMF colonization. A higher colonization of the roots must have led to a 
higher number of hyphae and a larger area of soil explored for nutrient extraction. Nitrogen, was not however as high in A. hypogea as in T. occidentalis. A possible explanation for this could be the need for protein formation in the seeds of the former whereas in the latter most of it might have been stored in the leaves where plenty of chlorophyll was probably being built up. The high foliar potassium concentration in C. esculenta and $I$. batatas could have resulted from the demand of these crops for this element for sugar translocation and starch synthesis being tuber crops (Reis Jr. and Fontes, 1996). The high foliar potassium concentration in Capsicum annum is also to be expected as previous findings have shown that this crop usually takes up more potassium than other elements (Santiago and Goyal 1985; Marcussi et al., 2004.)

\section{CONCLUSION}

Our study has shown that the soil of the Cross River Basin of Nigeria is rich in arbuscular mycorrhizal fungi spores and that these ten commonly cultivated crops of the area are all mycorrhizal fungi colonized. If this association is effectively managed the positive benefits of AMF can be used to maximize the production of these crops.

\section{ACKNOWLEDGMENTS}

The authors are sincerely grateful to the laboratory staff of Department of Soil Science University of Calabar, Calabar for their technical assistance.

\section{REFERENCES}

Bagyaraj, D. J and Manjunath, A., 1980. Selection of suitable host for mass production of VA mycorrhizal inoculation. Plant and Soil, 55, 495498.

Baylis, G. T. S., 1975. The magnoloid mycorrhiza and mycotrophy in root systems derived from it. In: Sanders, F. E., Mosse, B. and Tinker, P. B. (eds) Endomycorrhizas. Academic Press, London. 373-389.

Berch, S. M., Gamiet, S and Deom, E., 1998. Mycorrhizal status of some plants of southwestern British Columbia. Canadian Journal of Botany, 66, 1924-1928.

Bethlenfalvay, G. J and Newton, W. E., 1991. Agroecological aspects of the mycorrhizal, nitrogenfixing legume symbiosis. In: Keisicrand D. L. and Cregan, P, K. (Eds.) The Rhizosphere and Plant Growth, 349-354. Kluwer, Academic Publishers, Netherlands.

Daniels, B. A and Skipper, H. D., 1982. Methods for recovery and quantitative estimation of propagules from soil. In Methods and Principles of Mycorrhizal Research. Schenck, N.C., Ed. The American Phytopathological Society, St. Paul, MN.
Fagbola, O., Osonubi, O and Mulongoy, K., 1998. Growth of cassava cultivar TMS 30572 as affected by alley-cropping and mycorrhizal inoculation. Biology and Fertility of Soils, 27, 914.

Fitter, A. H and Merryweather, J. W., 1992. Why are some plants more mycorrhizal than others? An Ecological Enquiry. In: Read, D. J., Lewis, D. H., Fitter A. H. and Alexander, I. J. (eds). Mycorrhizas In Ecosystems. Pp 26-36. CAB International, UK.

Gadkar, V., Schwartz, R. D., Kunik, T and Kapulnik, Y., 2001. Arbuscular mycorrhizal fungi colonization factors involved in host recognition. Plant Physiol., 127, 1493-1499.

Gianinazzi, S and Scheuepp, H., 1994. Impact of arbuscular micorrhiza on sustainable agriculture and natural ecosystems. Basel, Birkhauser.

Giovanetti, M and Mosse, B., 1980. An evaluation of techniques for measuring vesicular - arbuscular mycorrhizal infection in roots. New Phytol. 84, 489-500.

Isobe, $\mathrm{K}$ and Tsuboki, Y., 1998. The relationship between growth promotion by arbuscular mycorrhizal fungi and root morphology and phosphorus absorption in gramineous and leguminous crops. Japanese Journal of Crop Science, 67, 347-352.

Juo, A. S. R., 1979. Selected methods for soil and plant analysis. IITA manual series No. 1, 70pp. IITA, Ibadan, Nigeria.

Koske, R. E and Gemma, J. N., 1989. A modified procedure for staining roots to detect VA mycorrhizas. Mycological Research, 92, 486488.

Marcussi, F. F. N., Bôas, R. L. V., de Godoy, L. J. G and

Goto, R., 2004. Macronutrient accumulation and portioning in fertigated sweet pepper plants. Sci. Agric. (Piracicaba, Braz.), 61, 622-68.

Okon, I. E., Osonubi O and Sanginga, N., 1996. Vesicular- arbuscular mycorrhiza effects on Gliricidia sepium and Senna siamea in a fallowed alley cropping system. Agroforestry Systems 33,165-175.

Plenchette, C., Fortin, J. A and Furlan, V., 1983. Growth response of several plant species to VAM: 1. Mycorrhizal dependency under field conditions. Plant and Soil, 70, 199-209.

Ryan, M. H and Angus, J. F., 2003. Arbuscular mycorrhizae in wheat and field pea crops on a low P soil: increased $\mathrm{Zn}$-uptake but no increase in P-uptake or yield. Plant and Soil, 250, 225239. 
Reis, Jr. R. A and Fontes, P. C. R., 1996. Qualidade de tubérculos da batateira em função de doses de adubação potássica. Horticultura Brasileira, 14, 170-174.

Santiago, C. L and Goyal, M. R., 1985. Nutrient uptake and solute movement in drip irrigated summer peppers. Journal of Agriculture of University of Puerto Rico, 69, (1): 63-68.

SAS Institute, Inc., 1996. Statistical Analytical Package for Windows. SAS Institute, Cary: NE, USA.

Sharif, M and Moawad, A. M., 2006. Arbuscular Mycorrhizal Incidence and Infectivity of Crops in North West Frontier Province of Pakistan. World Journal of Agricultural Sciences, 2, 123-132.

Sieverding, E., 1991. Vesicular-Arbuscular Mycorrhiza Management in Tropical Agrosystems. Deutsche Gesellschaft fur Technische Zusammenarbeit, Eschborn.

Sunilkumar, C. P., Seema, H. S and Garampalli, R. H.,

2012. Occurrence and distribution of arbuscular mycorrhizal fungi in agricultural fields of Mysore. World Journal of Science and Technology, 2, 01-07

Tageo., 2013. Tageo.com- NASA Goddard Space Flight Center, GPS city index \& satellite map<a href='http://www.tageo.com'>Courtesy of tageo.com</a>

Tarafdar, J. C and Marschner, H., 1994. Phosphatase activity in the rhizosphere of VA mycorrhizal wheat supplied with inorganic and organic phosphorus. Soil Biol. Biochem., 26, 378-395. 